\title{
Neotectonic Activity Using Geomorphological Features in the Iraqi Kurdistan Region
}

\author{
Varoujan K. Sissakian • Nadhir Al-Ansari (iD • Lanja H. Abdullah
}

Received: 1 January 2020/Accepted: 29 April 2020/Published online: 8 May 2020

(C) The Author(s) 2020

\begin{abstract}
Iraqi Kurdistan Region is located in the northeastern part of the Arabian Plate which is colliding with the Eurasian (Iranian) Plate and is located within the Zagros Foreland Basin. This collision, which is still active with convergent type of tectonic boundary, has caused deformation of the rocks in the Zagros Foreland Basin with different intensities. The deformation intensity decreases southwest wards since the exerted stresses from the collision is in a NE-SW direction. Depending on the deformation intensity and many other factors, the tectonic framework of the region which is part of the main tectonic frame of Iraq is divided into three main tectonic units among them only two units are within Kurdistan Region. The two zones are from NE-SW direction: (1) Shalair Terrane, and (2) Outer Platform. In the current study, evidences about Neotectonic activities are presented from different parts of
\end{abstract}

V. K. Sissakian

University of Kurdistan, Erbil, KRG, Iraq

e-mail: f.khajeek@ukh.edu.krd; varoujan49@yahoo.com

V. K. Sissakian

Private Consultant Geologist, Erbil, Iraq

N. Al-Ansari $(\bowtie)$

Lulea University of Technology, 97187 Luleå, Sweden

e-mail: nadhir.alansari@ltu.se

L. H. Abdullah

University of Sulaimani, Sulaimani, KRG, Iraq

e-mail: lanja.abdullah@univsul.edu.iq
Kurdistan Region depending on different geomorphological and structural features. Among those features are: abnormal trends of valleys, dislocated and dissected alluvial fans, regional lineaments, water and wind gaps, faulted rocks of Pliocene-Pleistocene age, active faults. The Neotectonic evidences were recognized using satellite images and the existing Neotectonic data, and validated in the field.

Keywords Neotectonic - Water gap · Wind gap · Pleistocene faults $\cdot$ Dissected alluvial fan $\cdot$ Active fault

\section{Introduction}

The Iraqi Kurdistan Region forms the extreme northeastern part of the Arabian Plate which is in collision with the Eurasian Plate with convergent type of plate tectonic boundary (Fouad 2015). The Zagros ThrustFold Belt through which the Zagros Foreland is located is formed due to the collision between the two plates, and the collision is still active. Many researchers have studied the tectonic activity of the collision, among them are: Berberian and King (1981), Beydoun (1991), Beydoun and Hughes Clarke (1992), Alsharhan and Nairn (1997), Blanc et al. (2003), Burberry et al. (2010), Burberry (2015) and Garzica et al. (2019), they all reported about the Zagros Foreland Basin which is a continuously subsiding 
basin including the Zagros Thrust-Fold Belt which itself includes different tectonic zones with different terminologies. However, the whole Iraqi Kurdistan Region lies in the Outer Platform (Unstable Shelf) which is tectonically unstable. Although different authors have different terminologies for different zones and/or units, but they all have assumed the same style of folding and their datings. Other researches have studied the effect of tectonics on the geomorphological forms, landscape and other indications which are related directly and/or indirectly with Neotectonic evidence, among them are: Bull and McFadden (1977), Rockwell et al. (1985), Burbank and Anderson (2001), Keller and Pinter (2002) and Dehbozorgi et al. (2010).

\subsection{Aim}

The current study aims to present Neotectonic evidences from different tectonic zones in the Iraqi Kurdistan Region and their relation and effects on the structural regime. Different examples are presented in the current study showing those Neotectonic evidences. Moreover, we have discussed the role and effect of the Neotectonic activity in the tectonic framework of the Iraqi Kurdistan Region.

\subsection{Previous Studies}

Neotectonic studies in Iraq as a whole and Iraqi Kurdistan Region as specific are rare. Some examples are mentioned: Al-Sakini (1975) attributed the growth of some subsurface anticlines in Kirkuk Plain to Neotectonic activities. Atomenergoexport (1985) constructed the Neotectonic frame work of Iraq within the Seismotectonic map. The basic of the Neotectonic was assumed to consider the contact between the Middle Miocene (end of the Marine environment) and Upper Miocene (beginning of the Continental environment) all over the Iraqi territory. Al-Janabi (1996) presented Geotectonic Model of the whole Iraqi territory following Atomenergoexport (1985) criteria. Sissakian and Deikran (1998) constructed the Neotectonic map of Iraq following Obruchev (1948) and the criteria of Atomoenergoexport (1985). Deikran (1998) presented Neotectonic data from the central part of Iraq. Sissakian (2010) recognized Neotectonic activity in Bazian area, North of Iraq. Sissakian et al. (2017) recognized Neotectonic activity along the contact between two main tectonic units, Inner and Outer Platforms. Elias et al. (2018) recognized Neotectonic activity from Alqosh vicinity in the northern part of Iraq. Sissakian et al. (2018) attributed the lateral growth of Qara Dagh anticline south of Sulaimaniyah to Neotectonic activities.

\section{Materials Used and Methodology}

For this study, the following material was used:

- Available topographical and geological maps of different scales.

- Available satellite images type Sentinel-2 downloaded from https://eos.com/landviewer/?lat=36. $32176 \& \operatorname{lng}=45.23346 \& z=9$

- Tens of published articles which deal with the aim of the current study.

There are many methods for indicating Neotectonic movements and construction of Neotectonic maps, like the "energy analysis method" and "analysis of the difference between the present and theoretical model of its development" (Markovic et al. 1996). Other methods use lineaments and tectono-geomorphic anomalies deduced from remote sensing data $\mathrm{Ku}-$ manan 2001). However, using the method of the elevation and/or the depth of the contact between Middle and Late Miocene rocks from the present topography (above the sea level) is another relevant method for deducing Neotectonic activities; especially when regional Neotectonic is concerned. This method was used because there is a Neotectonic map of Iraq (Sissakian and Deokran 1998) in which the mentioned data are presented. This is the same concept of Obruchev (1948) and was adopted by Atomenergoexport (1985) confirmed by Pavlides (1989), Markovic et al. (1996) and Koster (2005). Neotectonic movement (upward and down ward) is measured by constructed contours of reference geological surfaces (Fig. 1), from whom the amount and rates of Neotectonic movements can be calculated by dividing the minimum and maximum amounts on the concerned time intervals. The Neotectonic movements (upward and down ward) are measured by means of the constructed contours (Fig. 1). Accordingly, the amount and rates of the Neotectonic movements can be calculated. The upward and/or down ward 


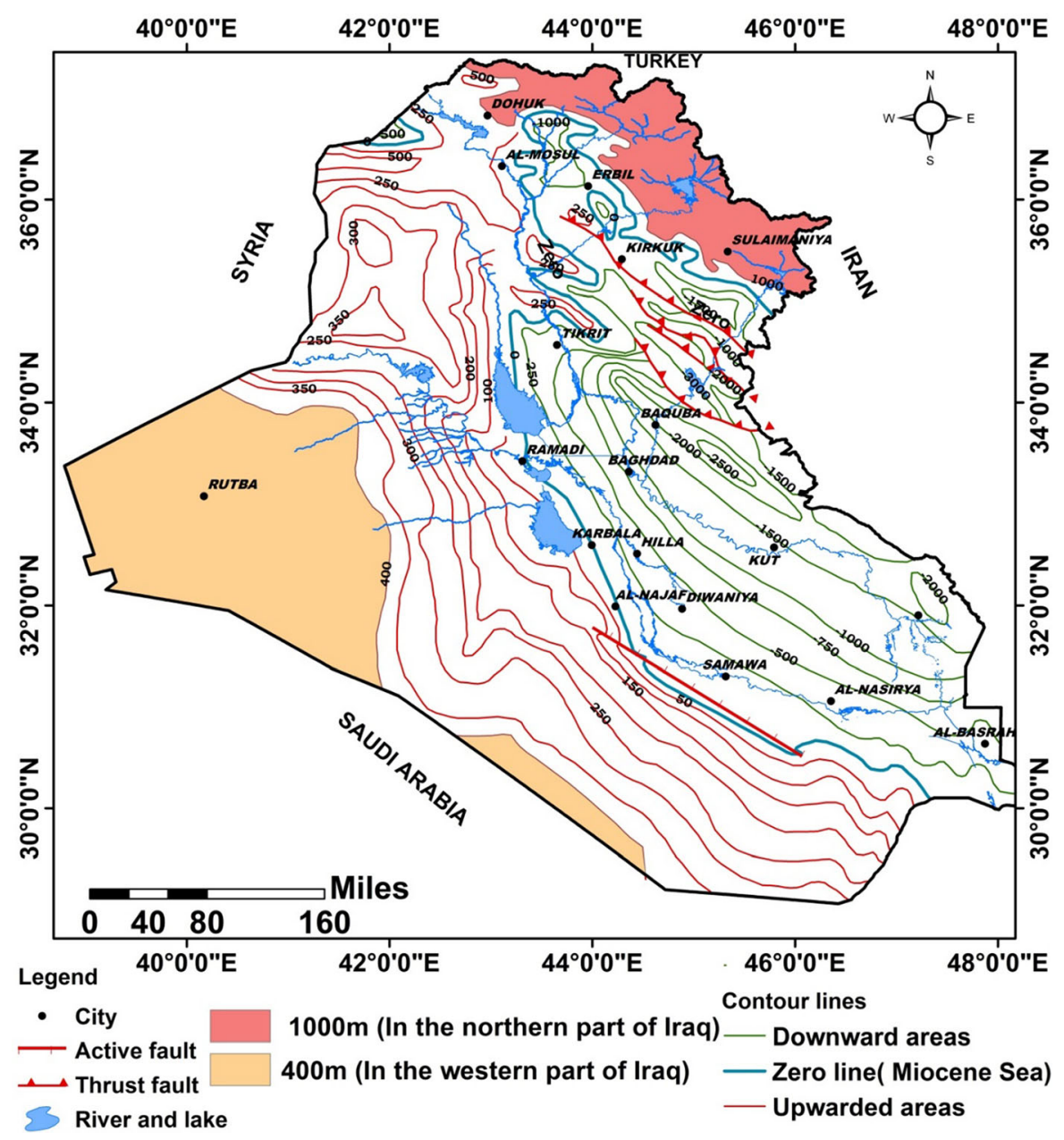

Fig. 1 Neotectonic map of Iraq. (Modified from Sissakian and Deikran 1998)

movements are easily deduced from the existing contours (Fig. 1). The rates of the upward and down ward movements are calculated by dividing the minimum and maximum amounts of upward and down ward movements on the concerned time intervals. For the Neotectonic period, the time interval is 11.62 Ma (Obruchev 1948), for the Pleistocene Epoch it is $2.588 \mathrm{Ma}$, and for the Holocene Epoch it is $11.7 \mathrm{ka}$ (ICS 2012).

In the Kurdistan Region, a lot of evidences occur indicating Neotectonic activities (Kumanan 2001). Geological and geomorphological maps with satellite imagery were interpreted in order to identify active Neotectonic forms in different parts of Iraq including the Kurdistan Region. Field work was performed during different time intervals by the senior author.

\section{Tectonic Frame Work of Iraqi Kurdistan Region}

The tectonic framework of Iraqi Kurdistan Region is a part of the tectonic framework of Iraq. However, because the geographical location of the Kurdistan Region is at the extreme north-eastern part of the Arabian Plate; therefore, the region has witnessed severe tectonic deformation due to the collision with the Erosion (Iranian) Plate. Besides, other exerted forces due to Anatolian Plate and related forces, as presented by the main Zagros Thrust Fault, Palmyra Fold Belt, East Anatolian Fault (Fig. 2).

The tectonic framework of Iraq (including Kurdistan Region) is well studied since the early 1980's and different tectonic maps are presented by different authors (Buday and Jasim 1984, 1987; Al-Kadhimi et al. 1997; Jassim and Goff 2006; Fouad 2015). All 


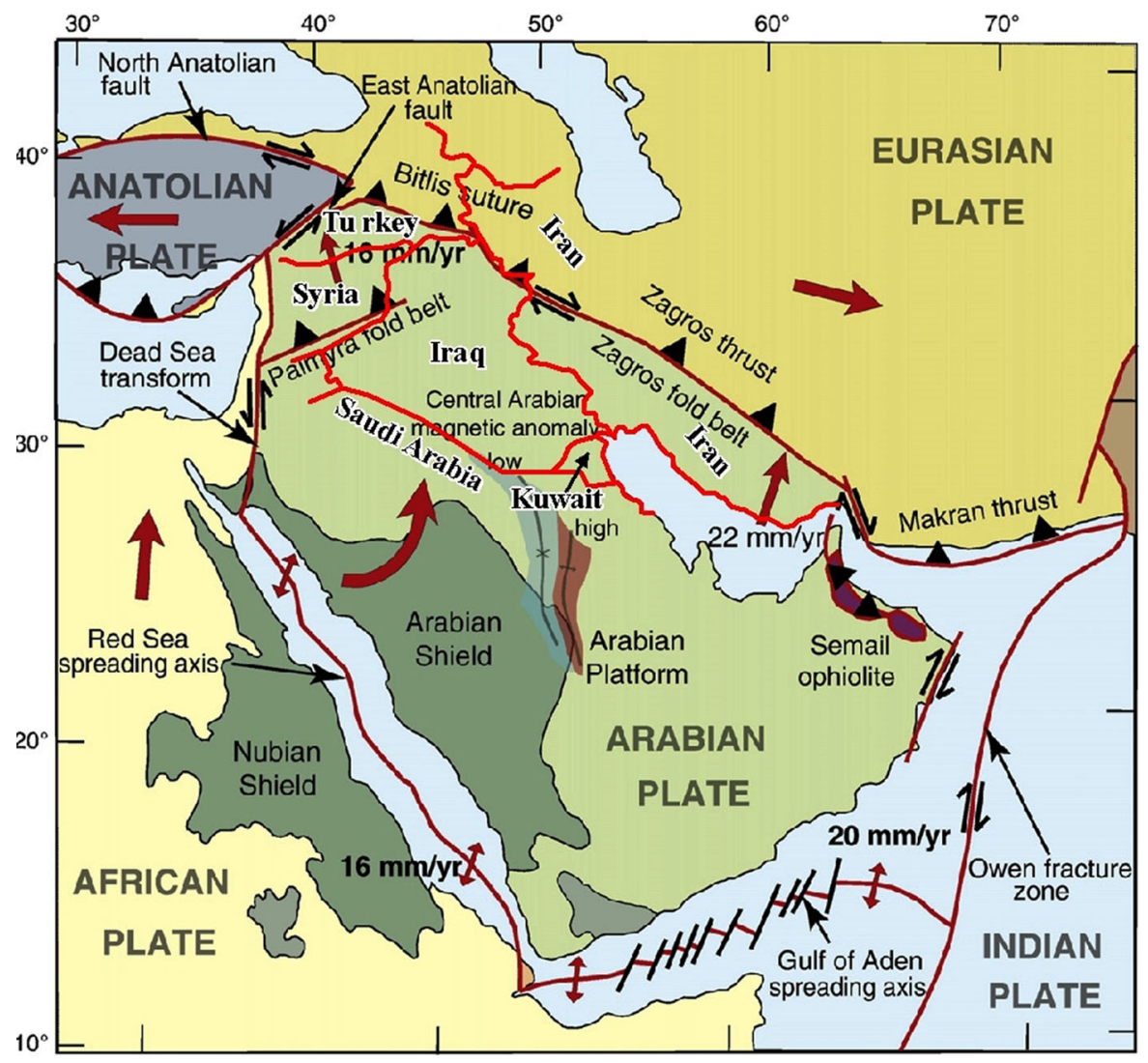

Fig. 2 Tectonic map of Saudi Arabia and surroundings (after Johnson 1998)

those authors have agreed upon the main tectonic framework of Iraq, being a part of the extreme northeastern margin of the Arabian Plate (represented by Kurdistan Region) which is in collision with the Iranian (Eurasian) Plate (Alavi 2004; Jassim and Goff 2006; Sissakian 2013). Different authors have used different terminologies for different tectonic units; nevertheless, they all agreed about the existence of two main parts: Stable Shelf (Inner Platform) and Unstable Shelf (Outer Platform). But, the tectonic contacts between those two main parts are quite different. The Kurdistan Region is totally located within the Outer Platform or Unstable Shelf which includes: (1) Imbricate Zone, High Folded Zone and Low Folded Zone; besides the Suture Zone and Shalair Terrane. In the current study, the Tectonic Map of Iraq (Fouad 2015) (Fig. 3) is adopted because the presented tectonic units are more applicable when compared with the tectonic frame work of Iraq, besides being the most recently published tectonic map of Iraq. The map shows the tectonic zones and subzones with the main structural elements; such as anticlinal axes, different types of faults. Moreover, some subsurface structural data are included in the map. However, because the original map is compiled at a scale of 1:1,000,000 (Fouad 2015). Therefore when the map was presented in A4 size, some of the details are blurred.

\section{Neotectonics}

The Neotectonic, which is attributed to Obruchev (1948), indicates the recent movements, occurred during the Late Neogene and Quaternary. Since then, no essential changes were introduced to the term "Neotectonic" although some authors have used the synonym term of "active tectonics". Others workers considered the beginning of the Neotectonic from the Middle Miocene (Pavlides 1989; Becker 1993; Markovic et al. 1996; Cloetingh et al. 2002; Koster 2005). However, Pavlides (1989) suggested that 


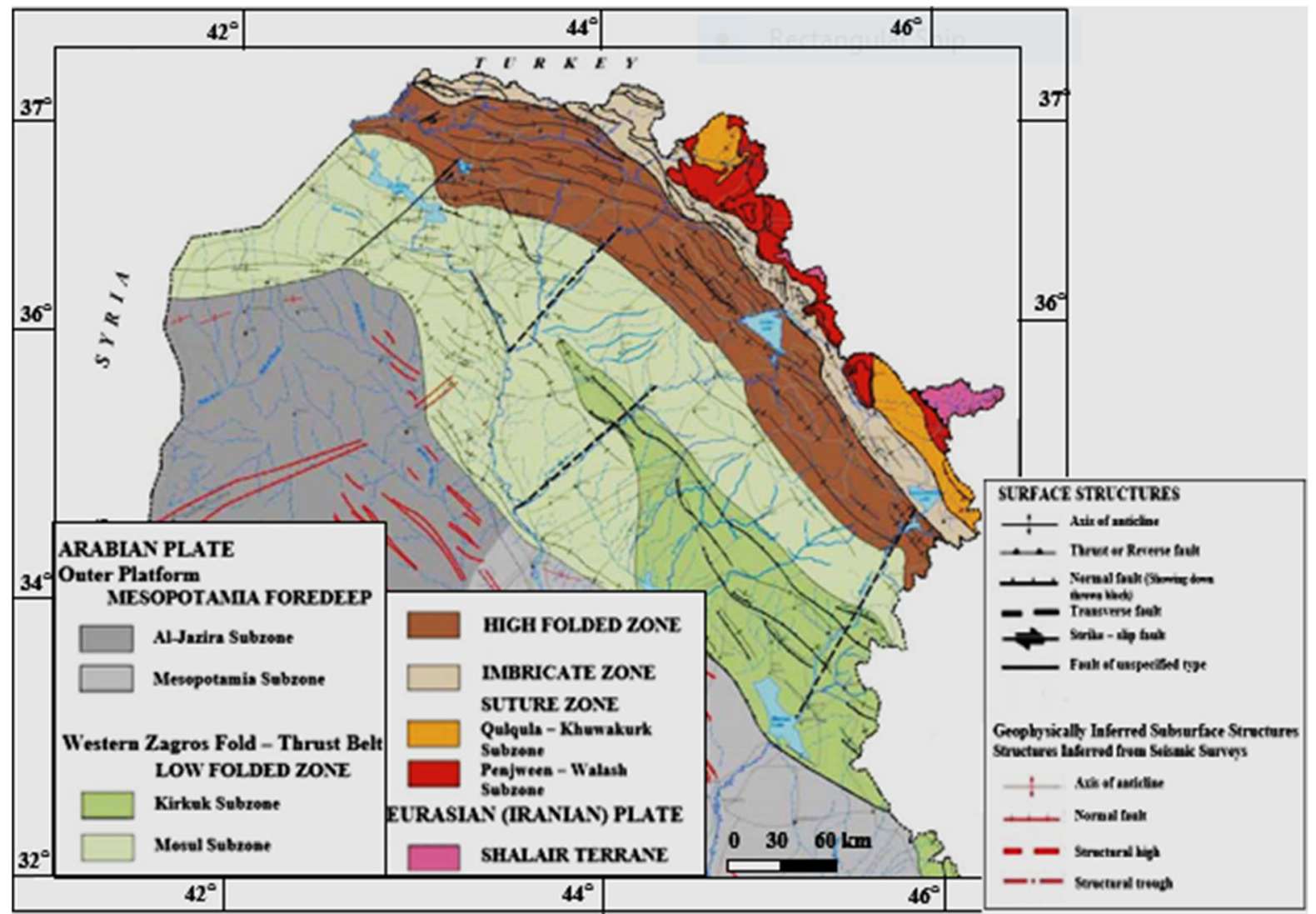

Fig. 3 Tectonic map of Iraq (Kurdistan Region) (Fouad 2015)

"Neotectonic is the study of young tectonic events, which have occurred or are still occurring in a given region after its orogeny or after its last significant tectonic set-up".

In Iraq including Kurdistan Region, the Neotectonic concept was used for the first time by Atomenergoexport (1985) considering the contact between the Fatha (Middle Miocene) and Injana (Late Miocene) formations because it represents the change from the last marine phase to continental phase. Sissakian and Deikran $(1998,2009)$ used the same concept in the compilation of the Neotectonic map of Iraq. However, in Kurdistan Region, the geological formations of Middle Miocene and younger are restricted to the extreme southern and north-western parts only. Therefore, no data is available to construct the Neotectonic map using the depth and/or height of the contact between Middle Miocene and Upper Miocene; accordingly, the majority of the region is considered to be elevated by more than $1000 \mathrm{~m}$ (Fig. 1).

\subsection{Neotectonic Movements in Kurdistan Region}

The Neotectonic movements (upward and down ward) are measured by means of the constructed contours (Fig. 1). Accordingly, the amounts and rates of the Neotectonic movements at different time intervals including the time span of the Upper Miocene (11.62 Ma), Pleistocene (2.588 Ma) and Holocene $(11.7 \mathrm{ka})$ are calculated and presented in Table 1. Moreover, many satellite images are interpreted and presented in the text.

At each tectonic zone, the maximum and minimum upward and down ward amount as measured by meters are presented in Table 1. This is acquired from the Neotectonic map of Iraq (Fig. 1). Moreover, the maximum and minimum rates of the upward and down ward movements are measured and presented by meters/1000 years for the Upper Miocene Period and by meters/100 years for the Pleistocene and Holocene Epochs. 
Table 1 Neotectonic data showing subsidence and upward amounts and rates

\begin{tabular}{|c|c|c|c|c|c|c|c|c|c|c|c|c|}
\hline \multirow[t]{4}{*}{ Tectonic units } & \multicolumn{12}{|c|}{ Neotectonic activity during } \\
\hline & \multicolumn{4}{|c|}{$(11.62 \mathrm{Ma})$} & \multicolumn{4}{|c|}{ Pleistocene (2.588 Ma) } & \multicolumn{4}{|c|}{ Holocene (11.7 ka) } \\
\hline & \multicolumn{2}{|c|}{$\begin{array}{l}\text { Subsidence } \\
\text { amount (m) }\end{array}$} & \multicolumn{2}{|c|}{$\begin{array}{l}\text { Upward amount } \\
\text { (m) }\end{array}$} & \multicolumn{2}{|c|}{$\begin{array}{l}\text { Subsidence } \\
\text { amount (m) }\end{array}$} & \multicolumn{2}{|c|}{$\begin{array}{l}\text { Upward amount } \\
\text { (m) }\end{array}$} & \multicolumn{2}{|c|}{$\begin{array}{l}\text { Subsidence } \\
\text { amount (m) }\end{array}$} & \multicolumn{2}{|c|}{$\begin{array}{l}\text { Upward amount } \\
\text { (m) }\end{array}$} \\
\hline & \multicolumn{4}{|c|}{ Rate (m/100 years) } & \multicolumn{4}{|c|}{ Rate (m/100 years) } & \multicolumn{4}{|c|}{ Rate (m/100 years) } \\
\hline 1 & 0 & $\begin{array}{l}3000 \\
0.026\end{array}$ & 0 & $\begin{array}{l}500 \\
0.0043\end{array}$ & 0 & $\begin{array}{l}700 \\
0.027\end{array}$ & 0 & $\begin{array}{l}111.36 \\
0.0043\end{array}$ & 0 & $\begin{array}{l}2.93 \\
0.025\end{array}$ & 0 & $\begin{array}{l}0.48 \\
0.004\end{array}$ \\
\hline 2 & 0 & 0 & $\begin{array}{l}250 \\
22\end{array}$ & $\begin{array}{l}1000 \\
0.0086\end{array}$ & 0 & 0 & $\begin{array}{l}55.68 \\
0.0022\end{array}$ & $\begin{array}{l}222.72 \\
0.0086\end{array}$ & 0 & 0 & $\begin{array}{l}0.24 \\
0.002\end{array}$ & $\begin{array}{l}0.97 \\
0.008\end{array}$ \\
\hline 3 & 0 & 0 & $\begin{array}{l}1000 \\
0.0086\end{array}$ & $\begin{array}{l}>1000 \\
>0.0086\end{array}$ & 0 & 0 & $\begin{array}{l}222.72 \\
0.0086\end{array}$ & $\begin{array}{l}>222.72 \\
0.0086\end{array}$ & 0 & 0 & $\begin{array}{l}0.97 \\
0.008\end{array}$ & $\begin{array}{l}>0.97 \\
0.008\end{array}$ \\
\hline 4 & 0 & 0 & $\begin{array}{l}1000 \\
0.0086\end{array}$ & $\begin{array}{l}>1000 \\
0.0086\end{array}$ & 0 & 0 & $\begin{array}{l}222.79 \\
0.0086\end{array}$ & $\begin{array}{l}>222.72 \\
0.0086\end{array}$ & 0 & 0 & $\begin{array}{l}0.97 \\
0.008\end{array}$ & $\begin{array}{l}>0.97 \\
0.008\end{array}$ \\
\hline
\end{tabular}

1-low folded zone, 2-high folded zone, 3-imbricate zone, 4-Zagros Suture zone

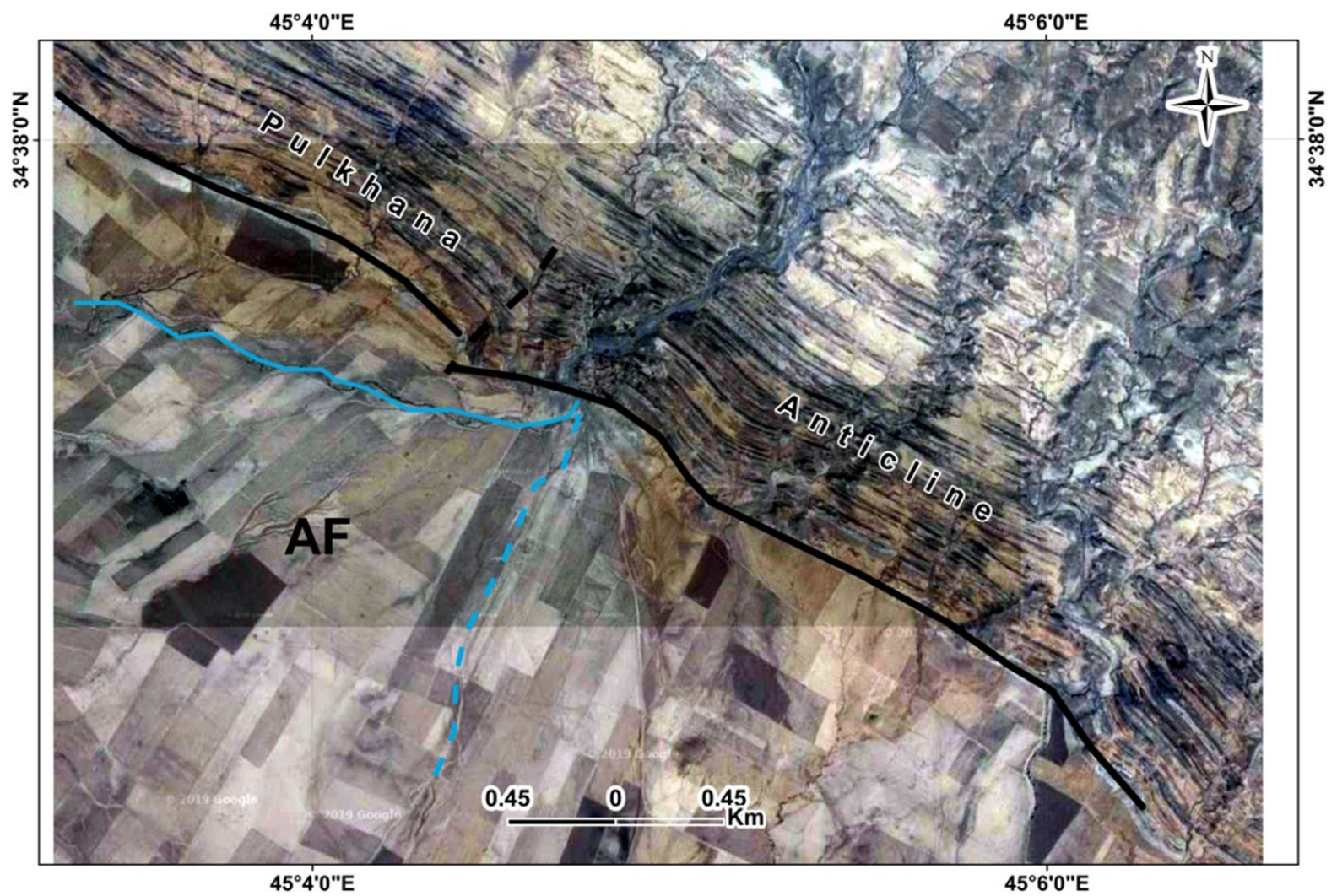

Fig. 4 Sentinel-2 image of Pulkhana anticline showing the dissected thrust fault (solid black line) by transversal fault (dashed black line). Note Abandoned alluvial fan (AF), with the abandoned feeder channel (dashed blue line) and a new feeder channel (solid blue line). https://eos.com/landviewer/?lat=36. $32176 \& \operatorname{lng}=45.23346 \& z=9$ 


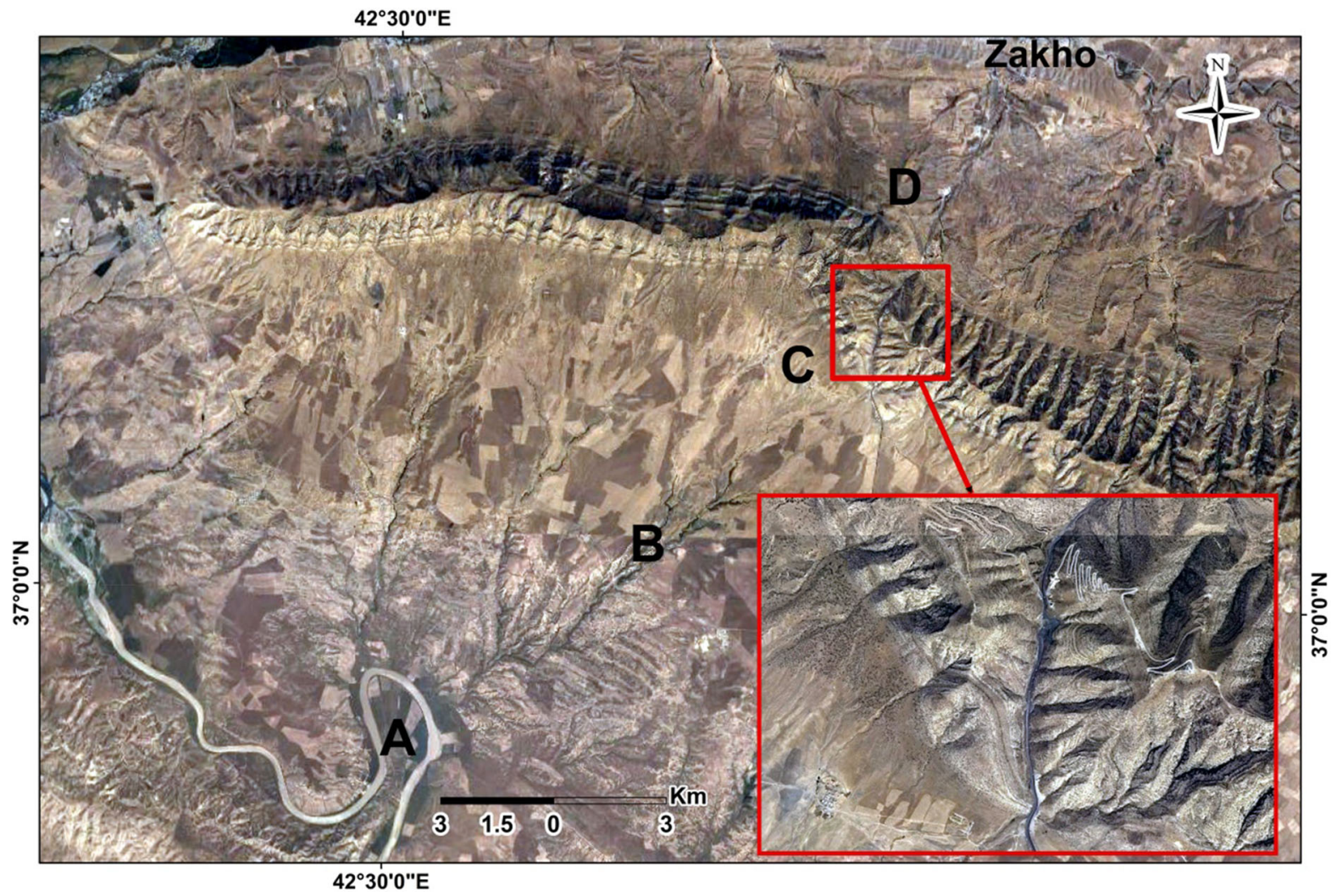

Fig. 5 Sentinel-2 image showing acute meander of the Tigris River and acute bend in Be'khair anticline south of Zakho town. Note the straight cliffs of the river along the same lineament (A-

\subsection{Neotectonic Indications from Iraqi Kurdistan Region}

Neotectonic indications can be found at different parts of Kurdistan Region and at different tectonic units. Neotectonic evidences are presented from each tectonic unit. Different types of indications and features are proposed by Oberlander (1985), Burbank and Anderson (2001), Keller and Pinter (2002), Ramsey et al. (2008) and Bretis et al. (2011).

\subsubsection{Low Folded Zone}

The Low Folded Zone covers the southern parts of Kurdistan Region and is characterized by long and narrow anticlines separated by wide and shallow synclines (Jassim and Goff 2006). The anticlines in the eastern part of the zone are characterized by thrust faults which run to the NW-SE anticlinal trend (Sissakian and Fouad 2014).
B-C-D) which has bended the anticline. https://eos.com/ landviewer $/$ lat $=36.32176 \& \operatorname{lng}=45.23346 \& z=9$

4.2.1.1 Pulkhana Anticline The northeastern limb of Pulkhana anticline (Fig. 4) is thrusted over the southwestern limb. Age of this thrust fault is estimated to be Pleistocene or younger because the rocks of the Bai Hassan Formation (Pliocene-Pleistocene) are dissected by the thrust fault. Moreover, the thrust fault is dissected too by transversal faults (Fig. 4), which means Neotectonic activity. The estimated displacement along this fault is around $120 \mathrm{~m}$. Abandoned alluvial fans with their original feeder channels are also good indication for Neotectonic activity (Burbank and Anderson 2001). Figure 4 shows one of those abandoned alluvial fans with feeder channel at Pulkhana anticline.

4.2.1.2 Be'khair Anticline Be'khair anticline is located in the extreme north western part of Kurdistan Region within the Low Folded Zone. Although it forms the contact between the Low Folded and High Folded Zones, we have considered 


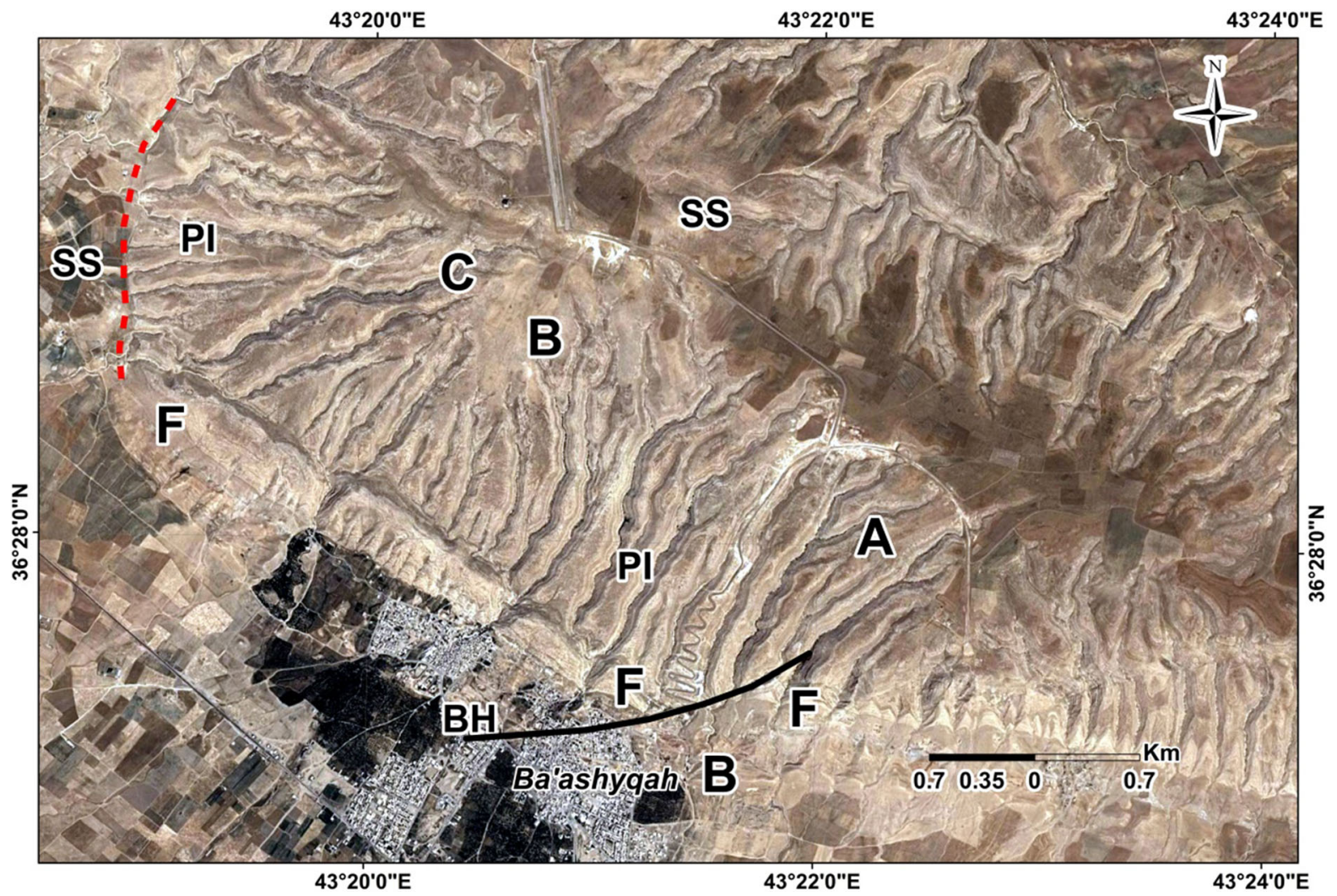

Fig. 6 Sentinel-2 image of Ba'shiqa anticline showing two faults. Dissected flatirons (black line) of the Fatha Formation (F) and hogbacks of the Bai Hassan Formation (B H). The straight ridge (red line) between rocks of the Pila Spi Formation

the example within the Low Folded Zone because the main evidence is within this zone (Fig. 5). The acute meander of the Tigris River is aligned on the same extension of a lineament which has caused bending of Be'khair anticlines along the line A-B-C (Fig. 5) with clear displacement of the beds which belong to the Bai Hassan Formation of Pliocene-Pleistocene age.

\subsubsection{High Folded Zone}

The following examples are presented.

\subsubsection{Ba'shiqa Anticline Another locality which} exhibits Neotectonic activity with clear geomorphological and structural features is Ba'shiqa Mountain (anticline). Two active faults were recognized (Fig. 6). The first one starts from NE of Ba'shiqa town and crosses the town; with NE-SE trend dissecting rocks of up to Pleistocene in age and the slope sediments (SS). Also note the shapes and trends of the valleys at points $\mathrm{A}, \mathrm{B}$ and $\mathrm{C}$. https://eos.com/landviewer/ ?lat $=36.32176 \& \operatorname{lng}=45.23346 \& \mathrm{z}=9$

which belong to the Bai Hassan Formation (PliocenePleistocene). Flat irons of the Fatha Formation and hogback of the Bai Hassan Formation show clear displacements (Fig. 6). The other fault is NW of $\mathrm{Ba}$ 'shiqa town with $\mathrm{N}-\mathrm{S}$ trend dissecting the rocks of the Pila Spi Formation (Eocene) and those of the Fatha Formation (Middle Miocene). Moreover. The fault forms a sharp straight ridge between the rocks of the Pila Spi Formation and the slope sediments which are derived from the former (Fig. 6). The fault is confirmed with the existing straight ridge which also confirms that the fault is active; otherwise, the contact between the rocks of the Pila Spi Formation and the overlying slope sediments (Pleistocene-Pliocene) wouldn't be a straight line.

Other Neotectonic evidences are the type, shape and trend of the valleys (Fig. 6). Fork-shaped valleys (Fig. 6; Point A), Curved valleys (Fig. 6; Point B) and radial valleys (Fig. 6; Point $C$ ). Another indication for 


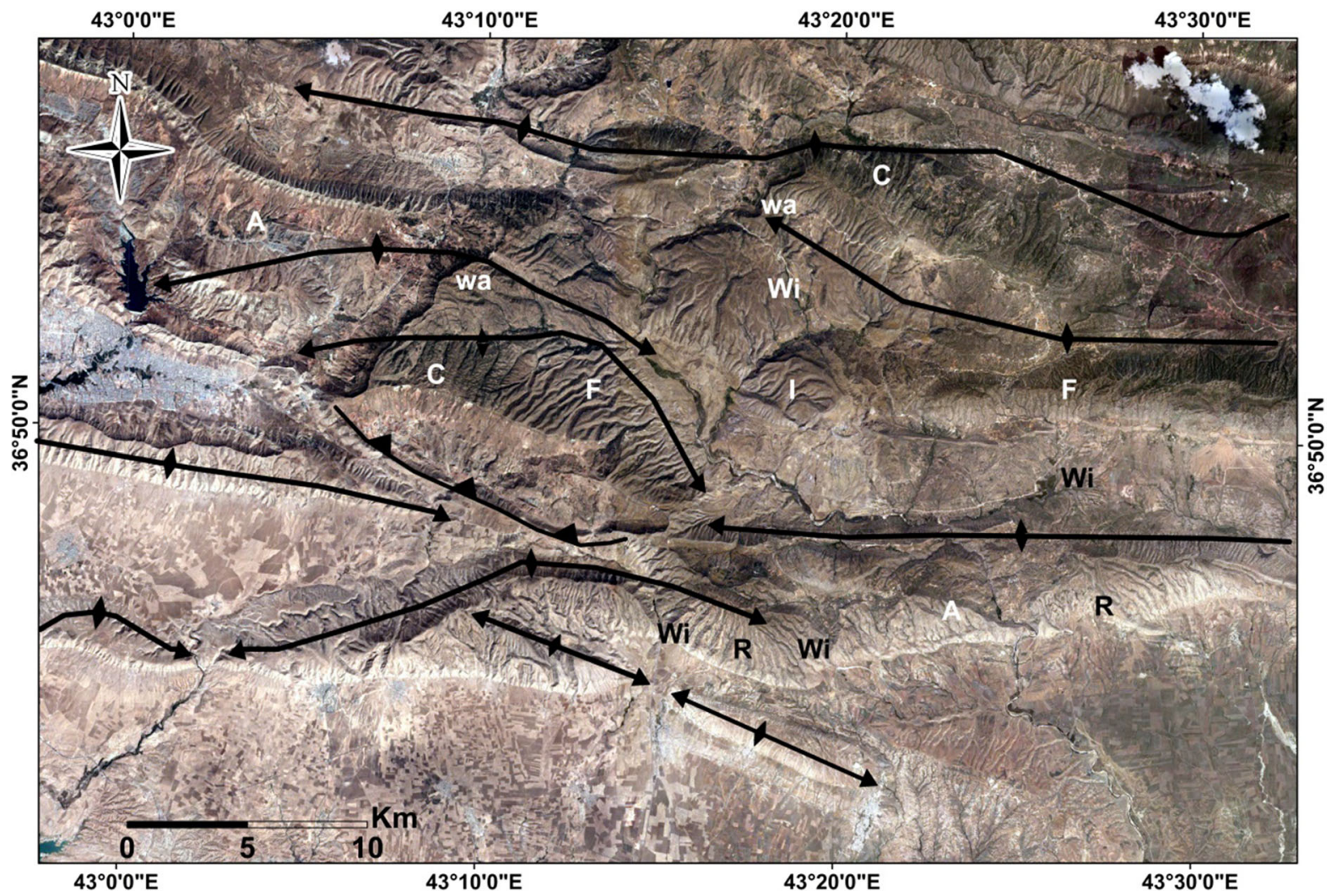

Fig. 7 Sentinel-2 image of Duhok east vicinity. Valleys: $A$ axial, $F$ fork-shaped, $R$ radial, $I$ inclined, $C$ curved. $W a$ water gap, $W i$ wind gap. Note The en-echelon pattern of plunging. https://eos.com/landviewer/?lat=36.32176\&lng=45.23346\&z=9

the Neotectonic evidence is the Whale-back shaped anticline. All these evidences were recognized in Ba'shiqa anticline.

\subsubsection{Duhok Vicinity In the East of Duhok} vicinity, many anticlines exhibit lateral growth with many geomorphological evidences (Fig. 7). It is one of the common areas which exhibit Neotectonic evidences. Among those evidences are: forked-shape valleys, axial valleys, radial valleys, cross-shaped valleys, inclined valleys, water and wind gaps, whaleshaped anticlines (Oberlander 1985; Burbank and Anderson 2001; Keller and Pinter 2002; Ramsey et al. 2008; Bretis et al. 2011). Moreover, the en-echelon plunging of some anticlines also indicate their lateral growths; accordingly, exhibiting Neotectonic activities. Such evidence is considered as a good indication for the lateral growth (Campbell 1958).

4.2.2.3 Ranya Alluvial Fans Large active (Haf) and inactive (Oaf) alluvial fans are present near Ranya
(Fig. 8). Four main active faults are present, which have dissected the existing ridges, we have numbered them as 1, 2, 3 and 4 (Fig. 8), and has caused the development of a large tectonic depression which is occupied by Dokan dam reservoir (Sissakian et al. 2016). The feeder channel of Ranya alluvial fan was running in $\mathrm{A}-\mathrm{B}-\mathrm{C}$ direction, but was shifted southwest wards by a transversal fault into its nowadays course (A-B-D; Fig. 8). The old alluvial fan of Ranya wouldn't be developed if the main feeder channel was not flowing in its old course A-B-C. Moreover, the fan is not active as the one in Hajiawa (HAf, Fig. 8) which is still active because the main feeder channel is shifted and started supplying sediments to the fan. Therefore, the fault and the shifted stream (the feeder channel) are considered as indication for Neotectonic activity. The faults in Fig. 8 have caused displacements to all existing ridges with amounts which range from 12 to $33 \mathrm{~m}$, all of them are normal faults with the eastern blocks being the down thrown ones. Through these displaced ridges, steams 


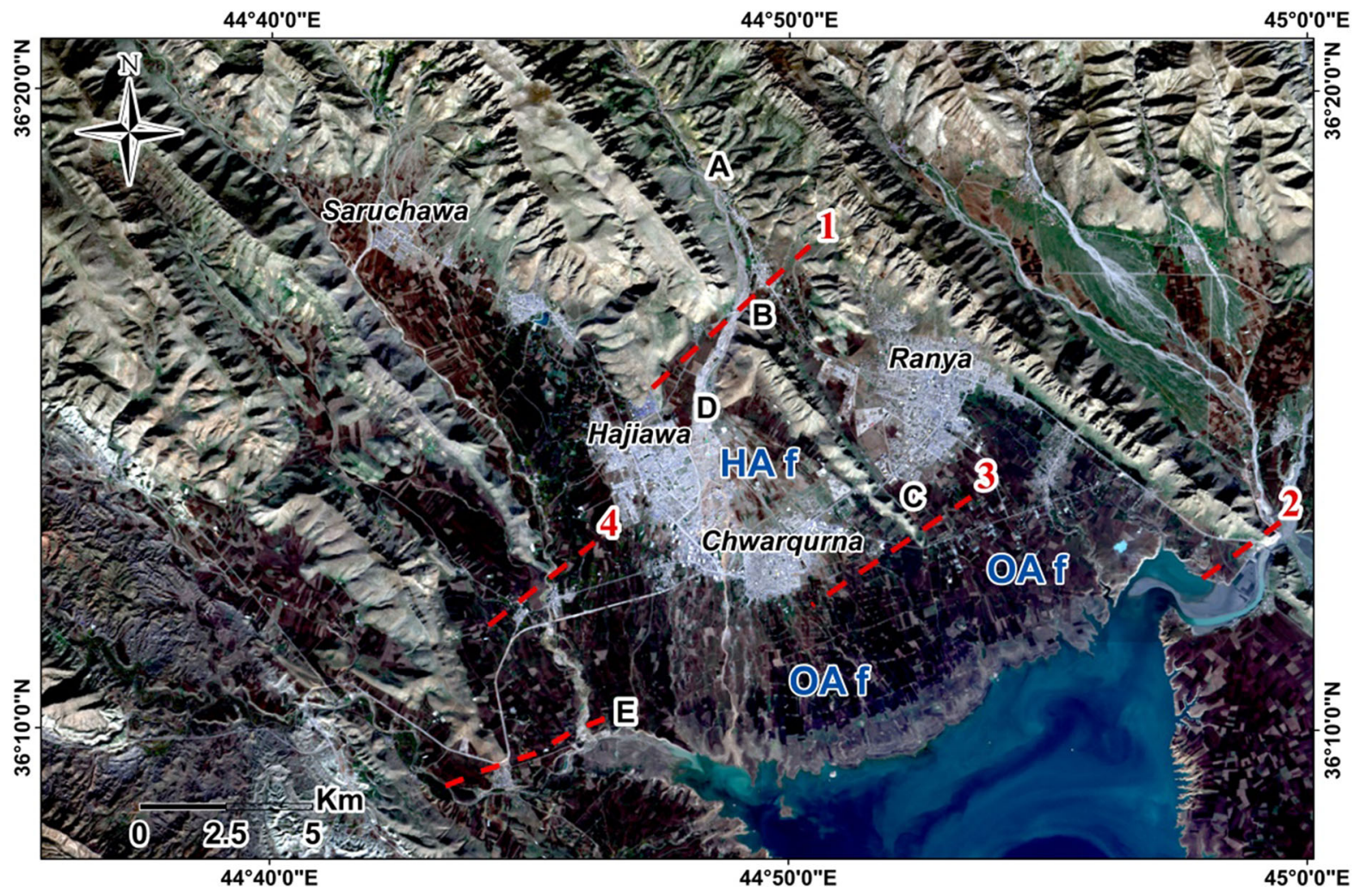

Fig. 8 Sentinel-2 image of Ranya alluvial fans. Note the 4 faults Nos. 1, 2, 3 and 4, and the shifted feeder channel (A-B-D); originally was running along (A-B-C). https://eos.com/landviewer/?lat=36.32176\&lng=45.23346\&z=9

are flowing and/or changed their courses; due to the displacement as shown at point B (Fig. 8, Fault No.1), where the steam was shifted and doesn't supply the alluvial fan near Ranya town. Other three faults (Fig. 8, Fault Nos. 2, 3 and 4) east and west of Chwarqurna town and south east of Ranya town have caused the disappearance of both ridges due to down ward movements. The three faults have formed a large tectonic depression which is occupied as Dokan Dam Reservoir. Figure 9 (top) shows one of the dissected ridges by Fault No. 1, whereas Fig. 9 (bottom) shows the displaced block (down ward) by Fault No. 2 which has appeared when the water level in the reservoir was dropped in 2017. The outcrops are continuation of the ridge which is dislocated at point $\mathrm{C}$ (Fig. 8).

\subsubsection{Imbricate Zone}

The Imbricate Zone is one of the most tectonically disturbed zones in Iraqi Kurdistan Region where majority of the existing anticlines are thrusted over their southern adjacent anticlines (Fouad 2015; Sissakian and Fouad 2012). The existing anticlines also exhibit lateral growth of folds with different structural and geomorphological indications. The following examples are presented.

\subsubsection{Amadiya Vicinity Gara anticline is one of} the major and long anticlines in the Imbricate Zone (Sissakian and Fouad 2014). The anticline is dissected by the Greater Zab River in a straight line valley (Fig. 10). It exhibits lateral growth with many geomorphological evidences which can be recognized from the satellite images. Among those indications are: Water gaps, wind gaps, forked-shape valleys, axial valleys, cross-shaped valleys, inclined valleys.

\subsubsection{Calcrete South of Penjween Calcrete is well} developed Pleistocene aged sediment along the slopes of Avroman Range (Fig. 11) which represents the contact between the Imbricate Zone and Zagros Suture 

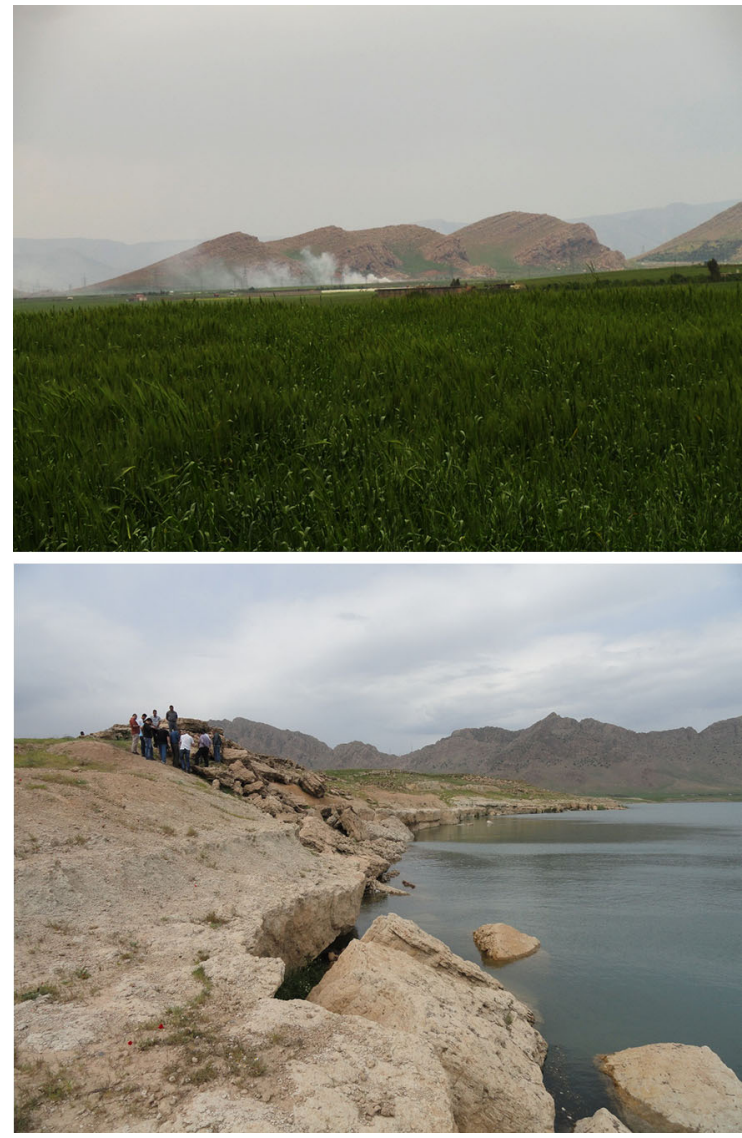

Fig. 9 (Top) One of the dissected ridges by a fault, (bottom) Uncovered exposures of the dissected ridge (Due to drop of the water level in 2017)

Zone (Sissakian and Fouad 2014). The calcrete is very thick and attains $300 \mathrm{~m}$, the base is very clearly inclined showing the original relief during the deposition. It forms very rugged topography which is dissected by deeply cut valleys. The Calcrete is highly deformed and locally even faulted (Figs. 11, 12); therefore, those faults are considered as Neotectonic. Moreover, the faults have segmented the alluvial fans into two different stages (Fig. 13), which is also an indication for the Neotectonic activity.

\subsubsection{Zagros Suture Zone}

Zagros Suture Zone is a long and narrow tectonic active zone (Fouad 2015). Although majority of the rocks are not sedimentary; however, the Qulqula Group is a sedimentary unit including thick clastic rocks of different types and sizes (Sissakian and Saeed 2012).

We have recognized a thrusted anticline in which only one limb is clear; however, the north western plunge is very clear (Fig. 14). Within this succession, many geomorphic indications for lateral growth were recognized like water gap, fork-shaped valleys and radial valleys (Fig. 14). These forms indicate Neotectonic activity.

\section{Results}

All tectonic zones in Iraqi Kurdistan Region exhibit Neotectonic activities. Different geomorphological and structural indications (features) can be seen in different parts of the region. The current study does not present quantitative evaluation for the recognized Neotectonic activities, this is attributed to the lack of detailed quantitative data and because the current study is a regional covering the whole Kurdistan Region. However, the intensity of the recognized features which indicate Neotectonic activity does not coincide with the decrease of the compressional forces south westwards due to the collision of the Arabian and Eurasian (Iranian) plates. This is attributed to the fact that majority of previous tectonic studies and maps have not considered the Neotectonic activity in their evaluations and considerations.

Majority of the anticlines in the Iraqi Kurdistan Region exhibit lateral growth which means Neotectonic activity. Moreover, tens of faults in the region are still active as indicated by their dissection of alluvial fans, streams, ridges, main thrust faults, Quaternary sediments. The minimum and maximum rates of upward and down ward movements during different age ranges were calculated using the Neotectonic map of Iraq (Fig. 1).

\section{Discussion}

The compressional forces exerted by the collision of the Arabian and Eurasian (Iranian) plates have developed tens of anticlines in Iraqi Kurdistan Region. The anticlines are of different sizes, orientations and exhibiting different fault types. All researchers (example Buday and Jassim 1984; Beydoun 1991; Berberian 1995; Alkadhimi et al. 1997; Blanc et al. 


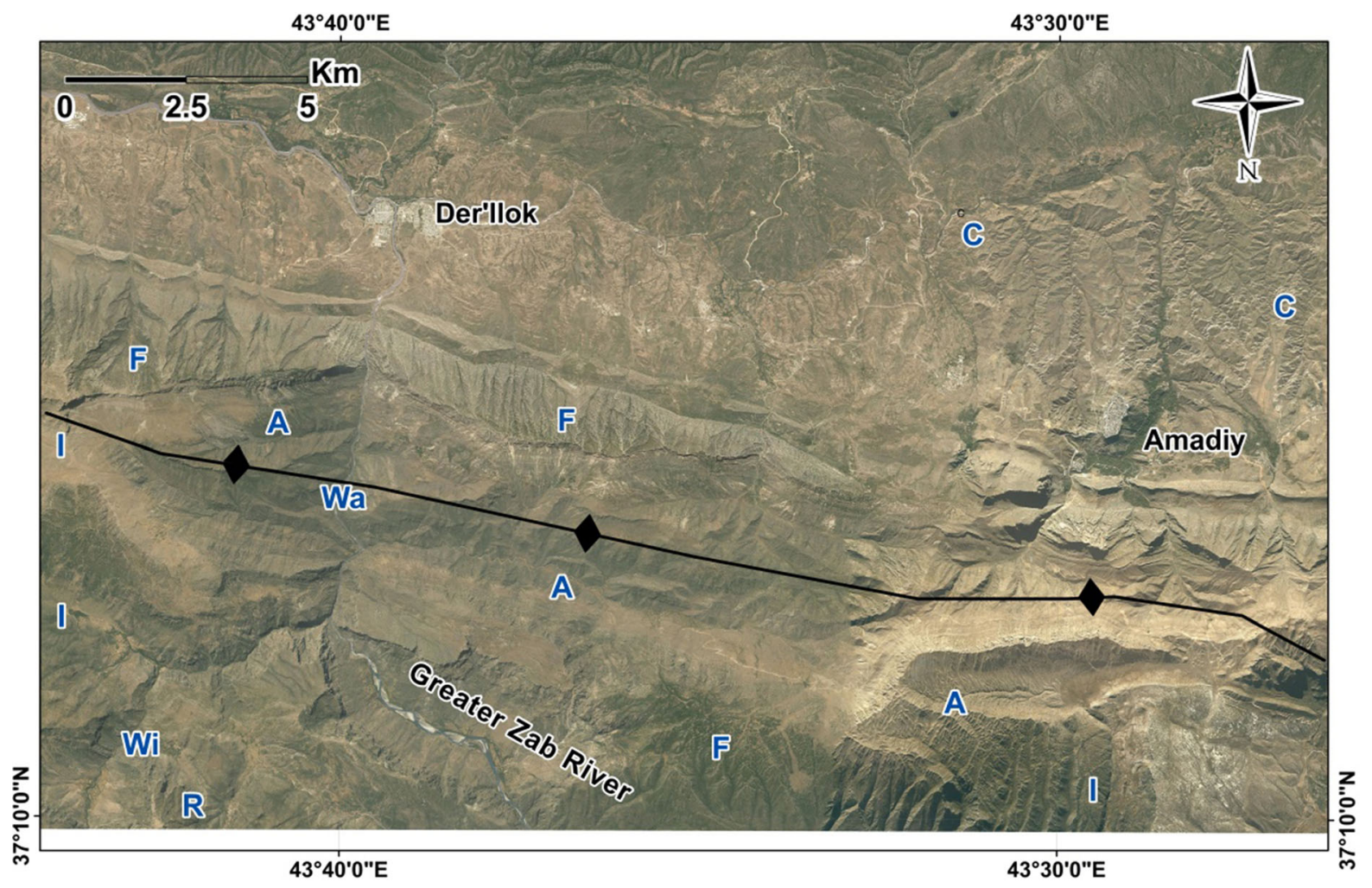

Fig. 10 Sentinel-2 image (facing south) of Amadiya vicinity. Note the developed evidences of lateral growths of the anticlines. Valleys: $A$ axial, $F$ fork-shaped, $R$ radial, $I$ inclined,
$C$ curved. Wa water gap, $W i$ wind gap. https://eos.com/ landviewer/?lat $=36.32176 \& \operatorname{lng}=45.23346 \& z=9$

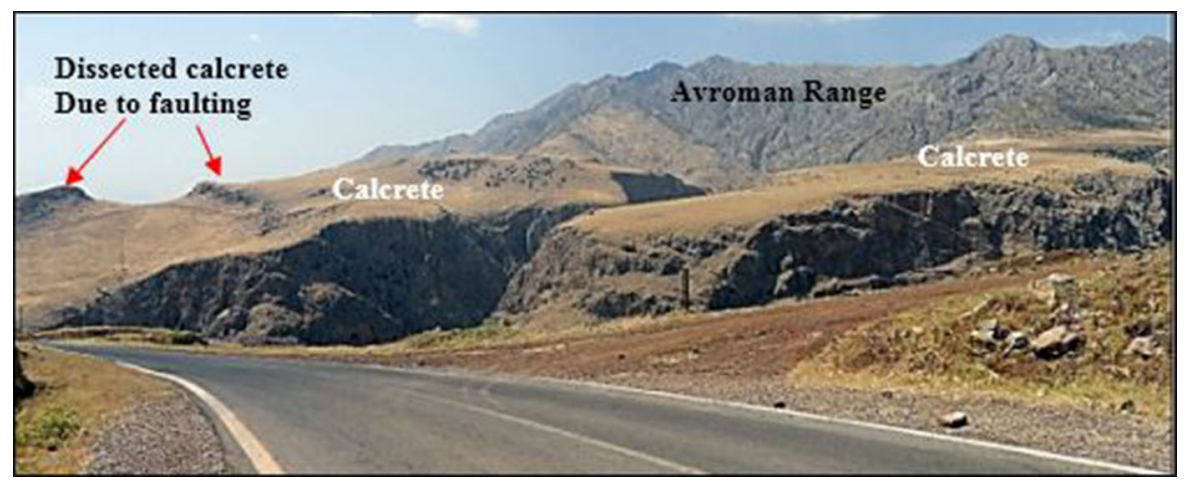

Fig. 11 The Avroman range in the background with faulted calcrete as indicated by tilting of the left block (down thrown) due to a normal fault

2003; Alavi 2004; Fouad 2015) have agreed upon that the folding intensity decreases southwards from the contact area between the two plates. However, none of the researchers included the Neotectonic activity and intensity in this statement.

The authors have recognized that all parts of Iraqi Kurdistan region with all tectonic zones exhibit
Neotectonic activities which are indicated by the presence of different structural and geomorphological forms. Among the former are the en-echelon plunges and faults of Pleistocene and/or younger ages, whereas among the latter are different shapes of valleys, abandoned alluvial fans, whale-back shape, water and wind gaps. However, no difference in the intensity and 


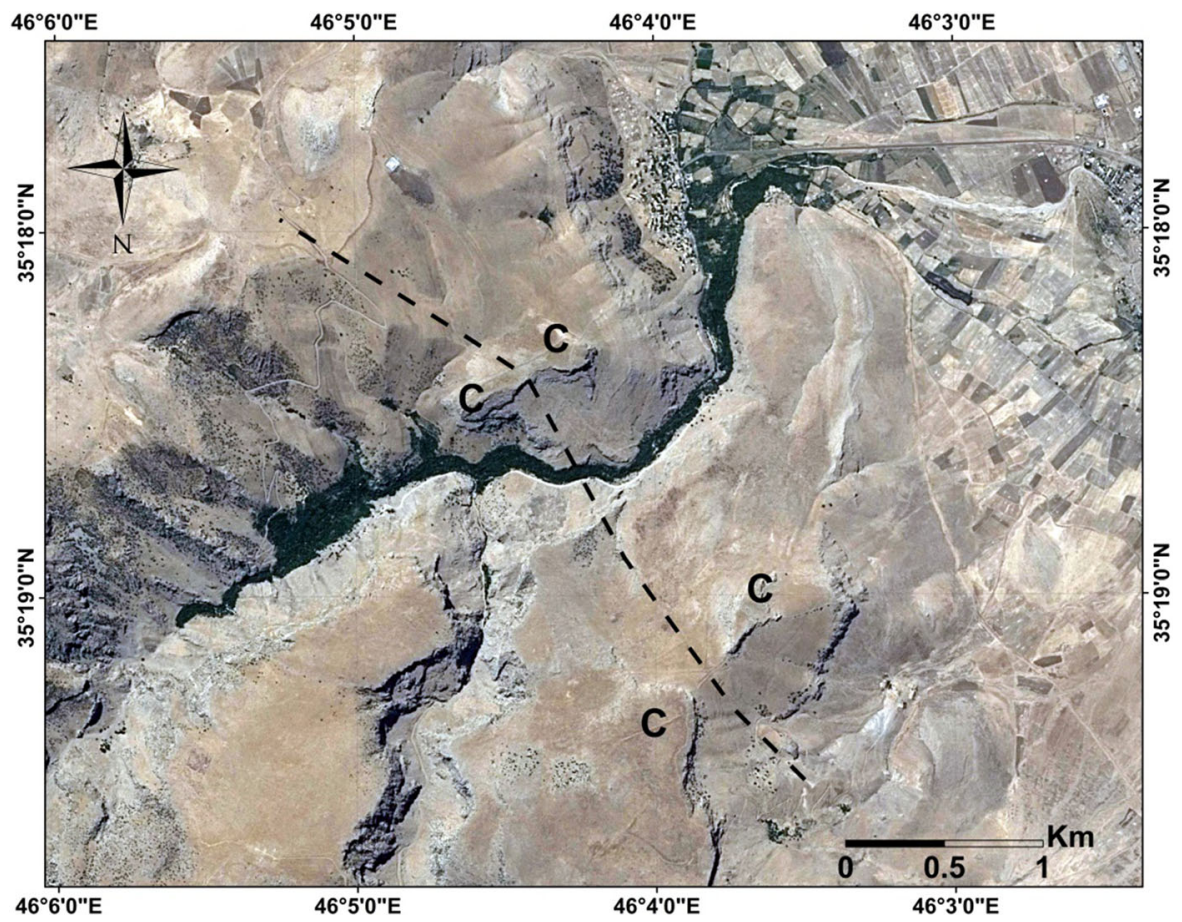

Fig. 12 Sentinel-2 image south of Penjween (near Khurmal town) showing the dissected calcrete (C) by a fault (the dashed line) in many places. https://eos.com/landviewer/?lat=36.32176\&lng $=45.23346 \& \mathrm{z}=9$

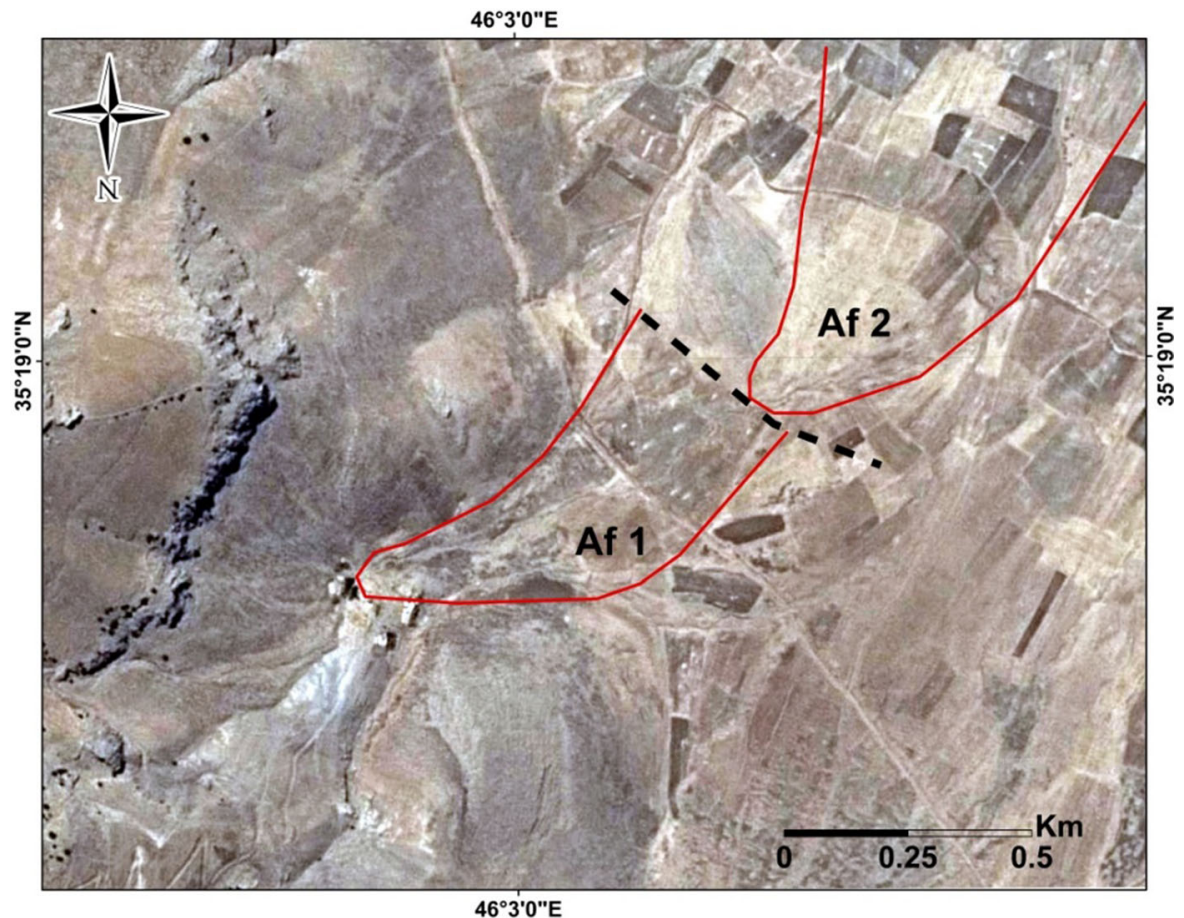

Fig. 13 Sentinel-2 images south of Penjween town (near Khurmal town) showing segmented alluvial fan (Af 1 and Af 2 , the red lines and the fault is presented by black dashed line). https://eos.com/landviewer/?lat=36.32176\&lng $=45.23346 \& z=9$ 


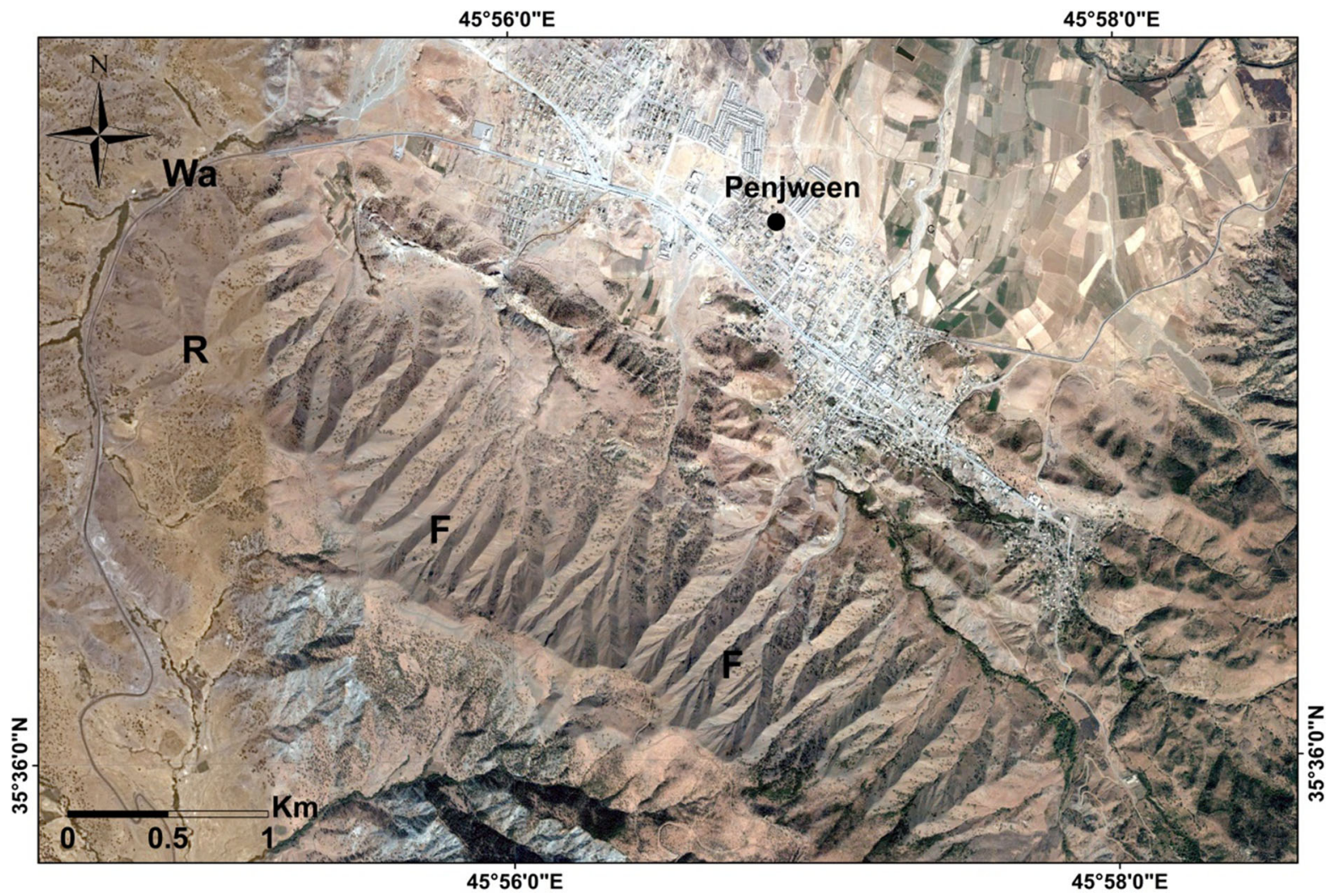

Fig. 14 Sentinel-2 image showing thrusted anticline with many geomorphic forms. Wa water gap, $F$ fork-shaped valleys, and $R$ radial valleys. https://eos.com/landviewer/?lat=36.32176\&lng=45.23346\&z=9

occurrences of those forms were recognized as the recognized difference in the intensity of folding which decreases southwest wards; as the contact between the two plates is considered. This can be attributed to: (1) the recognized tectonic forms are of Pleistocene age and younger which means they have formed during a limited time interval and not like the tectonic deformations which has started since the Cretaceous Period and onwards, (2) the recognized lateral folds' growths are also of Pleistocene age and younger, and (3) the recognized geomorphologic forms which indicate lateral growth of folds are also of Pleistocene age and younger since the present terrain is of Pleistocene age. Moreover, it is not possible to decide that there are differences in the intensity, sizes and shapes of the geomorphic forms which are related to the Neotectonic activities. Because the intensity, sizes, shapes and occurrences of those forms depends on the type of the rocks, competency, brittleness, their thickness, the individual bedding thickness, dip amount of the beds and their location within the fold.
Therefore, the authors believe that the Neotectonic activities are uniformly distributed in the whole Iraqi Kurdistan Region; in spite of all tectonic zones which exist in the region. However, in the Shalair terrane which forms the extreme north eastern part of the region and belongs to the Iranian Plate, the authors couldn't recognize any of the aforementioned tectonic and or geomorphic forms. This can be attributed to the very rare sedimentary rocks in the region. Although the geological map of Sulaimaniyah (Sissakian and Fouad 2014) shows many small anticlines in the region.

\section{Conclusions}

Iraqi Kurdistan Region exhibit Neotectonic activities in different parts of the region with the same intensity and occurrence in spite of the tectonic zones in which they occur. Majority of the identified evidences were recognized by interpretation of satellite images; some 
of the indications were checked in the field. The indications of the Neotectonic activities are either tectonic forms or geomorphic forms. The tectonic forms are represented by active faults which have dissected alluvial fans, ridges and main thrust faults, en-echelon plunging and rocks of Pleistocene ages. The geomorphic forms are represented by water gaps, wind gaps, fork-shaped valleys, radial valleys, inclined valleys, axial valleys cross-shaped valleys, and whale-shaped anticlines. The minimum and maximum rates of upward and down ward movements during different age ranges were calculated using the Neotectonic map and was found to range from $(0.0022-0.0086 \mathrm{~m} / 100$ years) and $(0.025-0.026 \mathrm{~m} /$ 100 years), respectively; as upward and down ward movements are concerned.

Acknowledgements Open access funding provided by Lulea University of Technology.

Open Access This article is licensed under a Creative Commons Attribution 4.0 International License, which permits use, sharing, adaptation, distribution and reproduction in any medium or format, as long as you give appropriate credit to the original author(s) and the source, provide a link to the Creative Commons licence, and indicate if changes were made. The images or other third party material in this article are included in the article's Creative Commons licence, unless indicated otherwise in a credit line to the material. If material is not included in the article's Creative Commons licence and your intended use is not permitted by statutory regulation or exceeds the permitted use, you will need to obtain permission directly from the copyright holder. To view a copy of this licence, visit http://creativecommons.org/licenses/by/4.0/.

\section{References}

Alavi M (2004) Regional stratigraphy of the Zagros fold-thrust belt of Iran and its proforeland evolution. Am J Sci 304:1-20

Al-Janabi MI (1996) Geotectonic model of Iraq. Unpublished M.Sc. thesis, University of Baghdad, Baghdad

Al-Kadhimi JM, Sissakian VK, Fattah AS, Deikran DB (1997) Tectonic map of Iraq, scale 1:1000000, 2nd edn. Iraq Geological Survey Publications, Baghdad

Alsharhan AS, Nairn AEM (1997) Sedimentary basins and petroleum geology of the Middle East. Elsevier, Amsterdam

Al-Sakini JA (1975) Usage of drainage pattern characteristics in determination of subsurface structures in plain around Kirkuk. J Geol Soc Iraq Spec Issue 8:45-53
Atomenergoexport (1985) Feasibility study of site selection for nuclear power plant location in Iraq, Book 3. Iraqi Atomic Energy Commission Library, Iraq

Becker A (1993) An attempt to define "Neotectonic period" for central and northern Europe. Int J Earth Sci 82(1):67-83

Berberian M (1995) Master "blind" thrust fault hidden under the Zagros folds: active basement tectonics and surface morphotectonics. Tectonophysics 241:193-224

Berberian M, King GCP (1981) Towards a paleogeography and tectonic evolution of Iran. Can J Earth Sci 18:210-265

Beydoun ZR (1991) Arabian plate hydrocarbon geology and potential. A plate tectonic approach. AAPG, Tulsa

Beydoun ZR, Hughes Clarke MW (1992) Petroleum in the Zagros Basin: a late Tertiary foreland basin overprinted onto the outer edge of a vast hydrocarbon rich PaleozoicMesozoic passive margin shelf. In: Macqueen RW, Leckie DA (eds) Foreland basin and fold belts, vol 55. AAPG Memoir, Tulsa, pp 9-46

Blanc EJP, Allen MB, Inger S, Hassani H (2003) Structural styles in the Zagros simple folded zone. Iran J Geol Soc Lond 160:401-412

Bretis B, Bartl N, Graseman B (2011) Lateral fold growth and linkage in the Zagros fold and thrust belt (Kurdistan, NE Iraq). Basin Res 23:615-630

Buday T, Jassim SZ (1984) Tectonic map of Iraq (A), scale 1:1000000, 1st edn. Iraq Geological Survey Publications, Baghdad

Buday T, Jassim SZ (1987) Tectonic map of Iraq (B), scale 1:1000000, 1st edn. Iraq Geological Survey Publications, Baghdad

Bull WB, McFadden L (1977) Tectonic geomorphology north and south of the Garlock Fault, California, Geomorphology in Arid regions. In: Doehring DO (ed) Publications in geomorphology. State University of New York, Binghamton, pp 115-138

Burbank DW, Anderson RS (2001) Tectonic geomorphology. Blackwell Scientific Publications, Oxford

Burberry CM (2015) The effect of basement fault reactivation on the Triassic-recent geology of Kurdistan, North Iraq. J Pet Geol 38(1):37-58

Burberry CM, Cosgrove JW, Liu J-G (2010) A study of fold characteristics and deformation style using the evolution of the land surface: Zagros simply folded belt, Iran. Papers in Earth and Atmospheric Sciences. University of Nebraska, Lincoln. Paper 295. https://doi.org/10.1144/SP330.8

Campbell JD (1958) En-echelon folding. Econ Geol 53:448-472

Cloetingh SA, Hotvath F, Bad G, Lankreijer AC (2002) Neotectonic and surface processes: the Panonian Basin and Alpine-Carpathian sysem. Eur Geosci Union Steph. Mueller Spec Publ Ser 3:1-7

Dehbozorgi M, Pourkermani M, Arian M, Matkan AA, Motamedi H, Hosseiniasl A (2010) Quantitative analysis of relative tectonic activity in the Sarvestan area, central Zagros. Iran Geomorphol 121(3):329-341

Deikran DB (1998) A preliminary neotectonic study of Al-Fatha Samarra Area, Central Iraq. Unpublished M.Sc. thesis, University of Baghdad, Baghdad

Elias Z, Sissakian VK, Al-Ansari N (2018) New tectonic activity within Zagros-taurus belt: a case study from 
north Iraq using Region Shuttle Radar Topography Mission. J Earth Sci Geotech Eng 8(1):51-63

Fouad SF (2015) Tectonic map of Iraq, scale 1:1000000, 3rd edn. Iraq Geological Survey Publications, Baghdad

Garzica EL, Vergésb J, Sapinc F, Saurab E, Meressec F, Ringenbachc JC (2019) Evolution of the NW Zagros fold-andthrust belt in Kurdistan Region of Iraq from balanced and restored crustal-scale sections and forward modelling. J Struct Geol 124:51-69

ICS (International Commission on Stratigraphy) (2012) International chronological chart. Brisbane, Australia, IGC 34

Jassim SZ, Goff J (2006) Geology of Iraq. Dolin, Prague and Moravian Museum, Brno

Johnson PR (1998) Tectonic map of Saudi Arabia. Ministry of Petroleum and Mineral Resources, Saudi Arabia

Keller EA, Pinter N (2002) Active tectonics: earthquakes, uplift, and landscape, 2nd edn. Prentice Hall, Upper Saddle River

Koster EA (2005) The physical geology of Western Europe, chapter 2: neotectonics. Internet Data. global.oup.com/ academic/product/the-physical

Kumanan CJ (2001) Remote sensing revealed morphotectonic anomalies as a tool to neotectonic mapping, experience from south India. Centre for Remote Imaging, Sensing and Processing, Singapore

Markovic M, Pavlovic R, Cupkovic T, Zivkovic P (1996) Structural pattern and Neotectonic activity in the Wider Majdanpek area, NE Serbia. Yugosl Acta Montan Slovaca Roc 1(2):151-158

Oberlander TM (1985) Origin of drainage transverse to structures in orogens. In: Morisawa M, Hack JT (eds) Tectonic geomorphology. Allen and Unwin, Boston, pp 155-182

Obruchev VA (1948) Neotectonics. In: Fairbridge RW (ed) 1968. Encyclopaedia of geomorphology. Dowden, Hutchinson and Ross Inc., Pennsylvania

Pavlides SB (1989) Looking for a definition of Neotectonics. Terra Nova 1(3):233-235

RamseyLA WRT, Jackson J (2008) Fold evolution and drainage development in the Zagros Mountains of Fars Province, SE Iran. Basin Res 20:23-48

Rockwell TK, Keller EA, Johnson DL (1985) Tectonic geomorphology of alluvial fans and mountain fronts near
Ventura, California. In: Proceedings of 15th annual geomorphology symposium. Tectonic Geomorphology, Boston, pp 183-207

Sissakian VK (2010) Neotectonic movements in Darbandi Bazian Area, southwest of Sulaimaniyah city. Iraqi Bull Geol Min 6(2):57-69

Sissakian VK (2013) Geological evolution of the Iraqi Mesopotamia Foredeep and inner platform, and near surrounding areas of the Arabian plate. J Asian Earth Sci 72(2013): 152-163

Sissakian V, Deikran DB (1998) Neotectonic map of Iraq, scale 1:1000000, 1st edn. Iraq Geological Survey Publications, Baghdad

Sissakian VK, Deikran DB (2009) Neotectonic movements in West Iraq. Iraqi Bull Geol Min 5(2):59-74

Sissakian V, Fouad SF (2012) Geological map of Iraq, scale 1:1000000, 4th edn. Iraq Geological Survey Publications, Baghdad

Sissakian V, Fouad SF (2014) Geological map of Sulaimaniyah Kirkuk Quadrangle, scale 1: 250000, 2nd edn. Iraq Geological Survey Publications, Baghdad, Iraq

Sissakian VK, Saeed ZB (2012) Lithological map of Iraq, compiled using GIS techniques. Iraqi Bull Geol Min 8(3): $1-13$

Sissakian VK, Abdul Ahad AD, Al-Ansari N, Knutson S (2016) The regional geology of Dokan area, NE Iraq. J Earth Sci Geotech Eng 6(3):35-63

Sissakian VK, Shehab AT, Al-Ansari N, Knutson S (2017) New tectonic findings and its implication on locating oil fields in parts of Gulf region. J Earth Sci Geotech Eng 7(3):51-75

Sissakian VK, Amin RM, Mohammed JG (2018) The lateral growth of Qara Dagh anticline, South of Sulaimaniyha City, NE Iraqi. A tectonic—geomorphological study. Iraqi Bull Geol Min 14(2):31-47

Publisher's Note Springer Nature remains neutral with regard to jurisdictional claims in published maps and institutional affiliations. 